\title{
液体窒素中における不平等電界下の 熱気泡挙動
}

$\begin{array}{llllll}\text { 正員 } & \text { 原 } & \text { 雅 } & \text { 則 } & \text { (九州大) } \\ \text { 准員 } & \text { 王 } & \text { 振 } & \text { 朝 } & \text { (九州大) } \\ \text { 准 員 齋 } & \text { 藤 弘 } & \text { 勝 } & \text { (九州大) } \\ \text { 准 員 村 松 } & \text { 悟 } & \text { (九州大) }\end{array}$

\section{Thermal-Bubble Behavior in Liquid Nitrogen under Non-Uniform Fields Masanori Hara, Member, Zhen-Chao Wang, Associate, Hirokatsu Saito, Associate, Satoru Muramatsu, Associate(Kyushu University)}

The behavior of bubbles in liquid nitrogen under non-uniform fields is studied experimentally and discussed on the basis of an analytical study on electrical forces acting on bubbles by the authors. A plane-to-cylinder with/without two dimensionaly triangular fins is used as the tested electrode and the orientation of the fin on the cylinder is chosen to be circular or longitudinal. The results are as follows : the macroscopic non-uniform field produced by the plane-to-smooth cylinder drives bubbles away to lower field region but bubble-aggregation appears when the electrical gradient force balances with the buoyancy; the microscopic non-uniform field by the fins locks bubbles in the groove between the fins and the bubbles move to a region of lower macroscopic field and are released into the surrounding liquid there. The bubble observation with different fins, circular fins and longitudinal fins on the cylinder, shows that the cylinder with the circular fins is optimum to guide the bubbles along the groove to a region of lower microscopic fields and to release them there. It is argued from the present study that the groove directed toward the gradient of the macroscopic non-uniform field on the electrode is effective for preventing both the vapor lock in the gap and the reduction in breakdown voltage and promoting the heat transfer from the electrode to liquid.

キーワード : 液体窒素, 絶緑破壊, 気泡, 冷却, グレディエントカ, マクスウェルストレス

\section{1.まえがき}

浸漬冷却の大型超電導コイルの超電導体には，冷却 安定性向上の権点からその表面にしばしばフィンが付 けられるが, フィンを付けると冷媒液体の耐電圧特性 は低下する。ところで, 超電導体のクエンチ時には導 体表面から気泡が発生するとともにコイルには誘導電 圧が発生し, 電気絶緑上厳しい状態になる。このよう な状態を模擬した平等電界電極系による気泡挙動の研 究によると(1)(2)，気泡がギャップをロックして耐電圧 が飽和ガスの值まで低下している。
フィンが付いた不平等電界ギャップの熱気泡破壊現 象に関してはほとんど研究されていない。著者らの気 泡に作用する力の解析を基にした理論的研究から (3), フィン付き不平等電界ギャップでは, 孤立気泡はグレ ディエントカによって低電界領域に押しやられるとと もにグレディエントカと浮力が平衡する所では気泡が 大きく集塊すると推定される。また，フィン先端では 安定に気泡が滞留し得ず,一方, フィン間の溝には気 泡がトラップされ，その気泡は，高電界領域ではマク スウェルストレスによって满からの離脱が困難になる のに対し，低電界領域では容易であると考えられる。 
本研究では, フィン付き不平等電界ギャップ中の熱 気泡挙動を実験により調べ，実験の結果と前報の理論 的研究(3) との比較からフィン間にトラップされた気 泡の状態推定を行い, 更に冷却促進に有効であるとと もに破壊電圧を低下させないフィン形状を見いだすこ とを目的とした。

\section{2. 実験の装置と方法}

〈2・1〉フィン付き超電導体ささきにも述べたよ うに, 浸漬冷却超電導マグネットのうち, 現段階での 大型コイルでは冷却を促進する立場から超電導体表面 にフィンを設ける場合が多い(4)。この場合, フィン形 状は, 電界が印加されていない場合の冷却促進, 製作 の容易さ, コイル巻きの容易さなどの面から決められ ており, 電圧印加時の気泡挙動と耐電圧を考慮したフ イン形状の検討は見られない。図 1 はフィン付き超電 導線断面の例で(5), この場合は導体長さ方向に主要な フィンが設けられているが, それと直角方向に設ける ことも考えられる。

〈2・2〉電 極 系 大型超電導コイルの導体は, 断面直径が $1 \mathrm{~cm}$ のオーダで, コイルターン間および 層間の液体で満たされる部分のギャップの長さは 1 $\mathrm{mm}$ のオーダである。本研究では, 電極間の電界解析 の容易さ, 実際の大型超電導コイルの導体系の寸法な どを考慮して, 電極系として図 2 のような円筒対平板 電極系を採用し, 電極寸法を図 3 のように円筒直径を $10 \mathrm{~mm}$, ギャップの長さ $d$ を $0.8 \mathrm{~mm}$ とした。また, フィンは図 1 およびその他の例を参考にして, 断面が 三角形の二次元構造とし, 寸法は図 3 のようにした。 なお, 電極表面は一連の機械工作後に化学研磨し, 更 にエタノール洗浄, 乾燥の後デュア内にセットした。

気泡挙動は重力 $G$ の方向と電界分布の方向との関 係に依存すると考えられるので, 電極系の配置は図 2

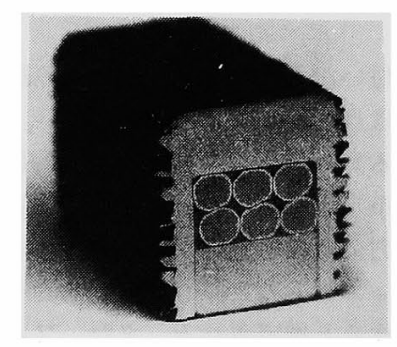

$\mathrm{Nb}_{3} \mathrm{Sb}$ Wire used for a JAERI Test Facility [ 5$]$

図 1 フィン付き超電導線の例

Fig. 1. Example of superconducting wire with fins. (a)のように 3 種類, また円筒電極表面状態, すなわ ちフィンの付け方は平滑表面も含めて (b)図のように 3 種類を実験対象とし, それぞれに図のような記号を 定めた。以下の議論では, 電極系の指定にこの表示を 用いる。また，ギャップ内の位置表示には，(a)図の

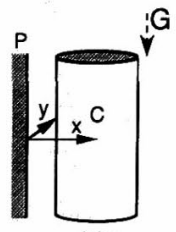

(I)
(II)

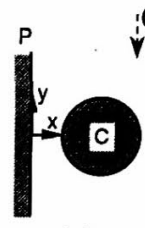

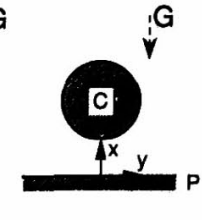

(III)
C : Grounded cylinder ,P : High voltage plane $-\rightarrow$ : Direction of gravitational force $(G)$

(a) Orientation of investigated electrode system

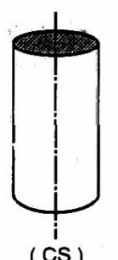

( CS )

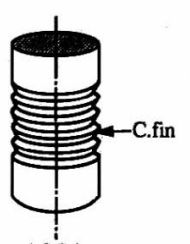

(c'c)

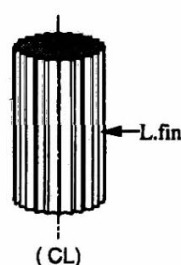

(CL)
Surface condition : CS : Smooth ; CC : Circular (C) groove $\mathrm{CL}$ : Longitudinal (L) groove

(b) Surface condition of cylindrical electrode

図 2 実験に使用した電極系 (円筒対平板) の 配置と円筒電極の表面状態およびそれらに 対する記号

Fig. 2. Orientation of investigated electrode system ( plane-to-cylinder), surface condition of cylindrical electrode and symbols for them.

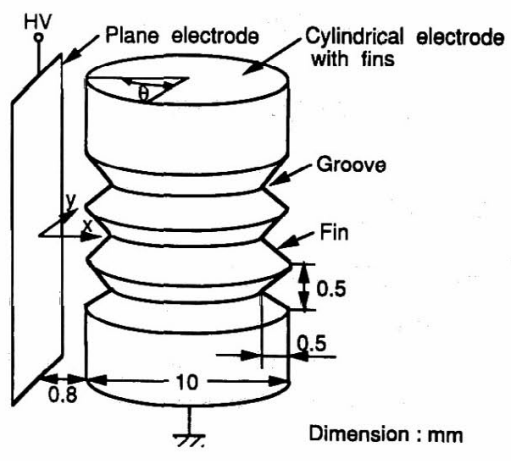

図 3 フィン形状と電極系の寸法 (I -CC 電極系の例)

Fig. 3. Dimension of the electrode system and fin ( I -CC electrode system). 


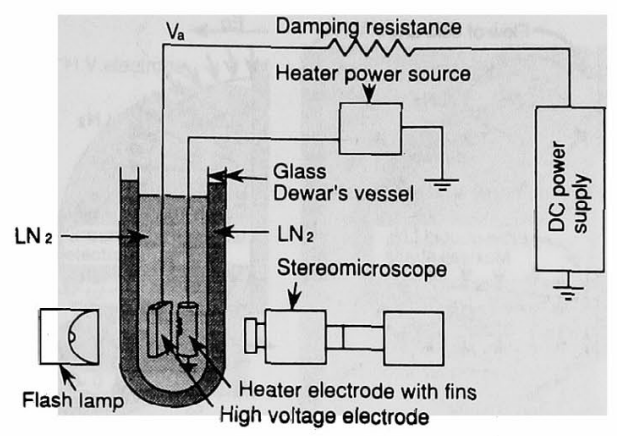

図 4 実験装置

Fig. 4. Experimental setup.

座標 $(x, y)$ を用い, 円筒電極の周りの位置表示が必 要な場合には図 3 のように $\theta$ を付加した。

円筒電極には超電導線のクエンチ時における発熱を 模擬するためにヒータを埋め込み，ヒータ入力を調整 して気泡の発生を制御した。ここでは, 円筒電極 $1 \mathrm{~mm}$ 当たりのヒータ入力を $H(\mathrm{~W} / \mathrm{mm})$ で表示した。

実験装置は図 4 のようで, 基本的には従来のもの ${ }^{(2)}$ と同じで，2 槽のデュアを液体窒素 $\left(\mathrm{LN}_{2}\right)$ で満たし， その中に電極系を浸した。従って, $\mathrm{LN}_{2}$ は大気圧沸 騰状態にあるが， 2 槽構造になっているので定常状態 になったときの電極近傍からの自然気泡はほとんどな u.

印加電圧は直流で, 気泡観測は $H$ と印加電圧 $V_{a}$ を定めて熱気泡が安定になった後に背面からストロボ で照射することによって行った。なお，気泡挙動に対 寸る極性効果はほとんど認められなかったが, 液体窒 素中における大気圧付近の針対平板ギャップの破壊電 圧は負針のほうが低いので，このことを考慮して本実 験では平板電極に正電圧を印加した。

\section{3. 気泡の観測結果と考察}

フィン付き導体間の電界は，前報 ${ }^{(3)}$ で述べたよう にフィンのない電極の作る不平等電界とフィンの付加 によるフィン近傍の局所的に発生する不平等電界の重 ね合せとして取り扱うことができ，著者らはこれらを それぞれマクロ不平等電界およびミクロ不平等電界と 呼んだ。本章ではまず，マクロ不平等電界中の気泡挙 動を述べ，次にミクロ不平等電界中の気泡挙動と気泡 状態を論ずる。

〈3・1〉 マクロ不平等電界中の気泡挙動

（1）実験結果 CS 電極を使って印加電圧なし で $H$ を増加させると，最初 $\mathrm{LN}_{2}$ は自然対流状態にあ るが, $H$ が $0.05 \mathrm{~W} / \mathrm{mm}$ 程度になると核沸騰状態に

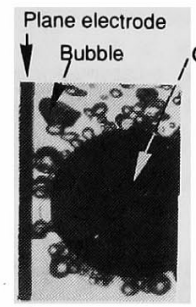

(i) $V_{a}=0 \mathrm{kV}$

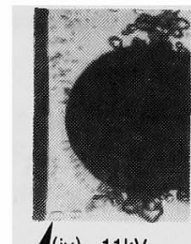

(iv) $11 \mathrm{kV}$ Aggregated bubble
Grounded cylinder without fin

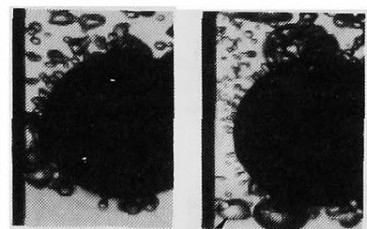

(iii) $7 \mathrm{kV}$ Aggregated bubble - Spark

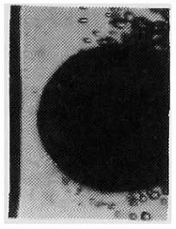

(v) $23 \mathrm{kV}$

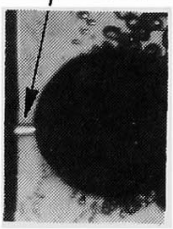

(vi) Breakdown
$H=1 \mathrm{~W} / \mathrm{mm}, \mathrm{d}=0.8 \mathrm{~mm}$

図 5 II-CS 電極系における高電界下の 気泡挙動

Fig. 5. Bubble behavior in the II-CS electrode system with DC high voltage.

なる。本来， $H$ を更に大きくするとやがて膜沸騰状 態に転移するはずである(6) が, 超電導線のクエンチ までの沸騰現象としては核沸騰状態に興味があること と本実験に使用したヒータ容量が大きくないために, ここでは主に核沸騰領域の気泡挙動を調べた。

図 5 は II-CS 電極系で活発な核沸騰が発生する七 一タ入力において, 印加電圧を変化したときの気泡挙 動を示す写真である。

印加電圧を上昇すると，円筒電極表面での気泡発生 点が増加するとともに気泡が小さくなる。円筒電極を 離脱した気泡は，グレディエント力の空間分布の計算 結果 ${ }^{(3)}$ から推定されるように, 高電界領域から低電 界領域方向へ駆動されている。下向きに駆動された気 泡は，次第に速度を落とし，ある位置 $\left(x_{t}, y_{t}\right) に お い$ て停滞し, 後から発生してその領域に到達した気泡と 合体して大きく成長する。更に, 合体した気泡はゆっ くり $x>0$ の方向に移動し, 円筒電極下部に沿って平 板電極と反対の側に放出される。印加電圧を上昇する と $y_{t}$ の值は大きくなる。

ギャップの長さが最短になる $y=0$ 近傍の気泡の個 数密度は電圧の上昇とともに小さくなるが, $H$ が大 きい場合には電気破壊近くの電圧でも円筒電極表面で の気泡の発生・成長が時間間隔をおいてではあるが認 められた。

図 6 は電極系がIII-CS の場合の気泡挙動である。 


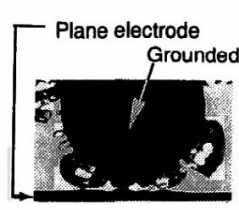

(i) $V_{a}=0 \mathrm{kV}$

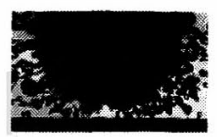

(iv) $10 \mathrm{kV}$

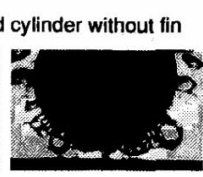

(ii) $3 \mathrm{kV}$

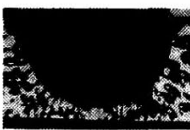

(v) $13 \mathrm{kV}$

$H=1 \mathrm{~W} / \mathrm{mm}, \mathrm{d}=0.8 \mathrm{~mm}$

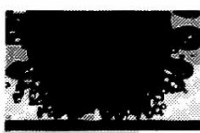

(iii) $5 \mathrm{kV}$

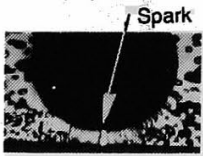

(vi) Breakdown

図 6 III-CS 電極系における高電界下の 気泡挙動

Fig. 6. Bubble behavior in the III-CS electrode system with DC high voltage.

電圧上昇に伴う気泡発生状況の変化は II - CS 電極系 の場合と同じであるが，孤立気泡が安定な滞留領域を 形成して大きく成長することはない。後述のフィンが ある場合の気泡挙動と比較するために, 高い印加電圧 において気泡が円筒電極からほほ放射状に多数放出さ れていることを指摘しておく。

(2) 考 察

（i） 円筒電極からの気泡離脱 よく知られてい るように, 電界がない場合の熱気泡は, 初期の半球状 から図 7 (a)-(i)のような茸状に成長した後, 電極 から離脱する(6)。電極表面上の気泡が半球状でこれに 電界がかかっていると, 気泡表面に作用するマクスウ エルストレスは, 平等電界中の球形気泡の場合と同じ で，(b)図のようになる。すなわち，図の $\mu$ 方向の表 面には

$$
p_{e}=\frac{q \varepsilon_{1}\left(\varepsilon_{1}-\varepsilon_{g}\right)}{2\left(2 \varepsilon_{1}+\varepsilon_{g}\right)^{2}} E_{0}^{2}\left(\varepsilon_{g} \cos ^{2} \mu+\varepsilon_{1} \sin ^{2} \mu\right)
$$

の圧縮応力が作用し, $p_{e}(\mu=\pi / 2) / p_{e}(\mu=0)=1.43$ と なり, 気泡は圧縮応力を受けつつ電界方向に長く変形 しようとする。ただし， $E_{0}$ は電極表面の外部電界, $\varepsilon_{g}, \varepsilon_{1}$ は気泡内ガスと周囲液体の誘電率である。 Garton らの平等電界中の孤立球形気泡に対する解析 によれば，気泡は偏長楕円体の形状を維持しながら変 形する。この場合, $\varepsilon_{g} / \varepsilon_{1}<20$ では液体の電気破壊以 前に気泡表面の不安定は生じないが, $\varepsilon_{g} / \varepsilon_{1}>20$ にな ると不安定が発生し得るようになり, 特に $\varepsilon_{g} / \varepsilon_{1}=\propto$ においては, 長軸と短軸の比 $\gamma か ゙, ~ \gamma=1.85$ になった 時点で気泡が不安定になって崩壊する。本研究の場 合, 気泡内で放電の発生がないと仮定すると $\varepsilon_{g} / \varepsilon_{1}=$ 0.7 であり, 放電が起こっていると仮定すると $\varepsilon_{g} / \varepsilon_{1}$

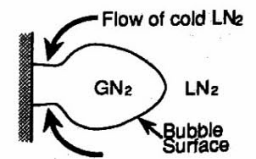

(i) Mushroom type bubble $(E=0)$

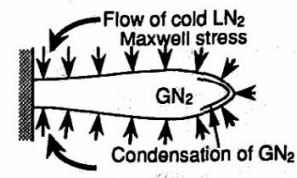

(ii) Elongated bubble by electric field $(E \neq 0)$

(a) Bubble shape on electrode at different fields.

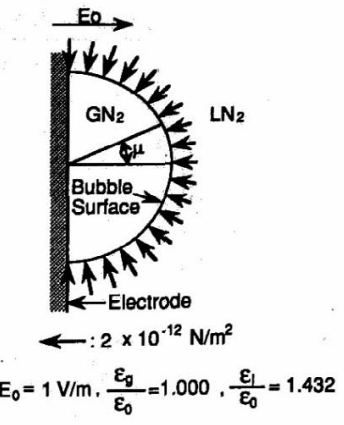

(b) Distribution of Maxwell stress on semi-spherical bubble surface.

\section{図 7 電極表面の気泡状態}

Fig. 7. Surface states of bubbles on electrode.

$=\propto$ となる。印加電圧が $10 \mathrm{kV}$ (電界にして, 約 12.5 $\mathrm{kV} / \mathrm{mm})$ では, 気泡内に放電は起こり得ないから, $\varepsilon_{g} / \varepsilon_{1}=0.7$ と考えられ, 理論上は $\gamma$ は 1 に近くなると 推定される。ところが図 6 では, $\gamma>2$ の気泡が多く 認められ，理論とは合わない。これは，気泡に作用す るマクスウェルストレスが液体の電気破壞直前(ギャ ップの長さ $1 \mathrm{~mm}$ 付近では, $E_{B}=20 \mathrm{kV} / \mathrm{mm}$ 程度)に は $600 \mathrm{~N} / \mathrm{m}^{2}$ 程度になり, 気泡内蒸気圧が飽和圧力よ り $0.6 \%$ 程度高い過飽和状態になって, 特に気泡先端 で蒸気の液化が発生することと[図 7 (a) - (ii)], 対 流によって気泡の根本に冷たい $\mathrm{LN}_{2}$ が入り込んで電 極近傍での収縮が促進されるためと考えられる。すな わち, ガスと液体の温度が同じ非圧縮性気泡に電界が かかったとする Garton らの計算におけるょり, 液体 の蒸発とガスの液化が同時に進行している本研究の場 合のほうが, 同じ電界に対して電極表面上の気泡変形 が見掛け上大きくなっている。

このような気泡の細長い変形が, 電界下の孤立気泡 の粒径を小さくしている原因になっていると考えられ る。更に, 電界印加の前後で電極内の熱発生量が一定 の場合, 放熱量を一定に保つために電界印加によって 気泡が小さくなったことを補うように気泡発生点が増 えたと考えられる。

（ii）孤立気泡の滞留・合体 前報(3)で, 孤立気 泡に作用するグレディエントカ $F_{g}$ の鉛直下向き成分 が浮力 $F_{B}$ に等しくなる領域で気泡の滞留・合体が起 こり得ることを指摘した。気泡を球形と仮定して 11 $\mathrm{kV}$ 時の II-CS 電極系における $y_{t}\left(x_{t}\right)$ を前報の理論解 析(3)により推定すると図 8 (a)のようになる。観測 


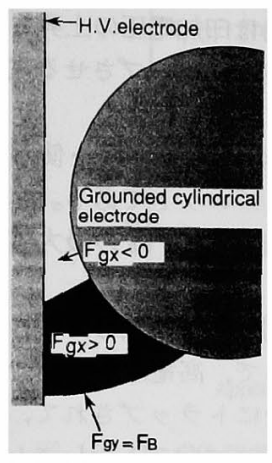

(a) Estimated bubble-stagnation region

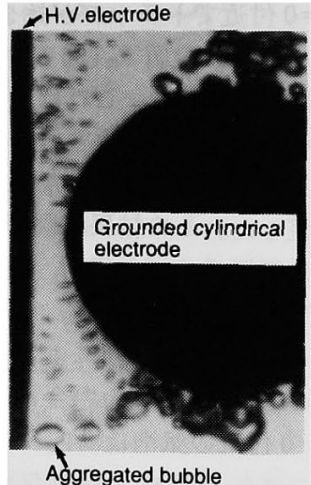

(b) Observed bubbles
$H=1 W / \mathrm{mm}, \mathrm{d}=0.8 \mathrm{~mm}$

図 $8 \quad$ II -CS電極系における $11 \mathrm{kV}$ 電圧印加時 の気泡滞留領域の計算值と理論值の比較

Fig. 8. Comparison of theoretical and experimental stagnation regions of bubbles with the II - CS electrode system under applied voltage of $11 \mathrm{kV}$.

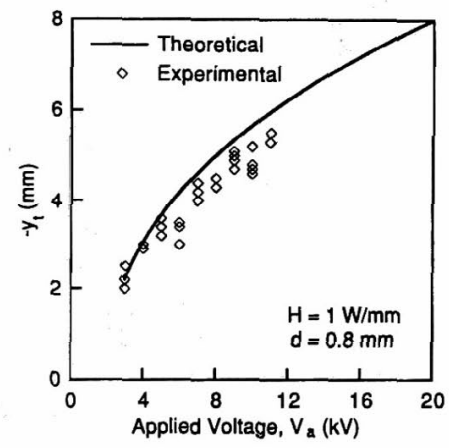

図 9 気泡滞留位置の電压依存性 (II-CS 電極系)

Fig. 9. Voltage dependence of bubblestagnation location with the II-CS electrode system.

結果〔(b)図了は気泡の滞留が起こると推定される $F_{g y}\left(x_{t}, y_{t}\right)=F_{B}$ に扔いてそれが発生していることを 示しており，理論とよく合っている。たた゚し， $F_{g y}$ は $F_{\theta}$ の $y$ 方向成分である。

いま, II-CS 電極系で $y_{t}\left(x_{t}=0.4 \mathrm{~mm}\right)$ を印加電压 の関数として理論と実験より求めると図 9 のようにな ク，両者はよく合っている。同図より，II-CS 電極系 では, 気泡の滞留・合体はギャップの電気破壊近くの電 圧において $y=0$ から遠く離れた領域に形成され，合 体した気泡は電気破壊現象に影響しないといえる。

ところで, III-CS 電極系の場合, $y=0$ 付近の平板

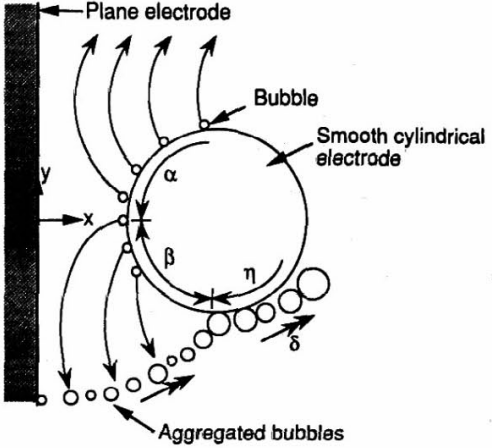

図 10 平滑円筒電極の場合の気泡の基本挙動 Fig. 10. Basic behavior of bubbles with smooth cylinder-to-plane gap.

近傍でグレディエントカの下向き成分と浮力が等しく なる領域が存在するが，図 6 では䫒著な気泡の滞留・ 合体は認められない。これは，浮力による気泡に対す る電極からの煣離力が小さいために, 破壊電圧付近ま で気泡が円筒電極に接触した状態のまま平板近くまで 長く伸び, 孤立気泡の形成が不十分なためである。

（iii） 平滑表面円筒電極系における気泡の基本挙動 上記の得られた結果を他の電極系にも適用できるよ うに, II - CS 電極系を例にとり, 平滑表面円筒電極 系における気泡の基本挙動をまとめると次のようにな る。

（a） $H$ が小さい場合, 電圧印加によって気泡の 発生点は少なくなるが，活発な核沸騰が起こる $H$ に おいては, 気泡発生点はむしろ増え, 孤立気泡粒径が 小さくなる。

（b）グレディエントカと浮力の方向が一致する領 域(図 10 の $\alpha$ の領域)では, 電界により電極からの気 泡剝離が促進されるが，下向きのグレディエントカが 浮力より大きくなる領域(同図の $\beta$ の領域)では孤立 気泡は重力に逆らって下向きに運動し, 両者が平衡す る点で滞留・合体を引き起こす。更に合体して大きく なった気泡(同図の $\delta$ ) は，グレディエントカの $x$ 方 向成分に上り水平に駆動される。図のII-CS 電極系 では, 右方向に駆動され，電極表面を伝って電極系外 へ放たれている。

（c）最短ギャップ領域（図 $\alpha / \beta$ の境付近）には, 破壊電圧まで気泡の発生成長が認められる。これは，破 壊電圧が熱気泡の影響を受けることを暗示している。

\section{$\langle 3 \cdot 2\rangle$ ミクロ不平等電界下の気泡挙動}

（1）実験結果 気泡に作用する電気力の計算か ら, 電極表面にフィンを付けた場合, 高電圧印加時に 
気泡はミクロ不平等電界によってフィン間の溝にトラ ップされることが推定された ${ }^{(3)}$ 。電極での発熱が継続 されている場合，溝にトラップされた気泡はいつかは 溝外に放出されなければならない。この放出過程を調 ベる目的で， I-CC，III-CC，III-CL 電極系で気泡挙 動が詳細に調べられた。

図 11 は I-CC 電極系で $\theta=0$ における気泡をギャ ップの横方向から撮影した写真である。また，図 12 はIII-CC 電極系で円筒電極の軸方向から撮影した写 真である。このように, $\theta$ 方向に溝のある CC 電極の 場合, 電圧印加によって低い電圧から $\theta=0$ 付近の洴 への気泡トラッブが始まり, 電圧の上昇に伴ってトラ ップの領域が $\theta$ の大きいマクロ不平等電界の低い領 域に広がる。すなわち, CC 電極での溝内の気泡挙動 の模式図は図 13(i ) のように描かれ, 溝にトラップ された気泡は, 電極の配置にほとんど関係せず, 最初

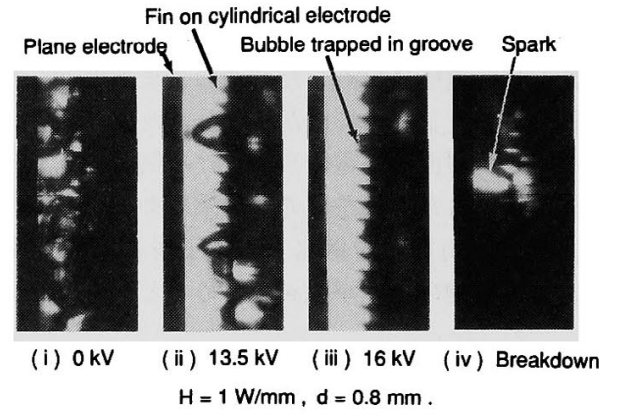

図 11 I-CC 電極系に扔ける高電界下の 気泡挙動

Fig. 11. Bubble behavior in the I-CC electrode system with $\mathrm{DC}$ high voltage.

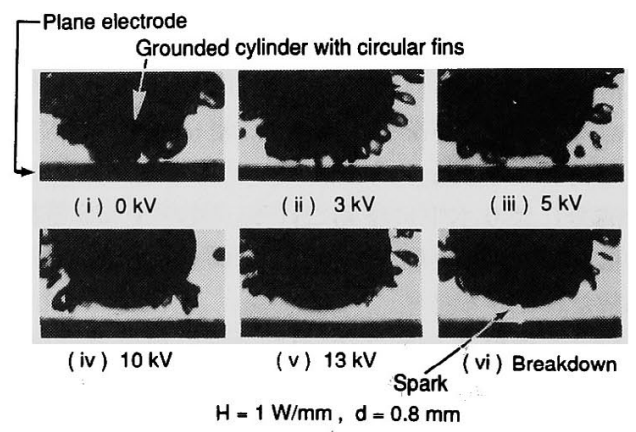

図 12 ШI-CC 電極系における高電界下の 気泡挙動

Fig. 12. Bubble behavior in the III-CC electrode system with DC high voltage. $\theta=0$ 付近でトラップが始まり, 溝から気泡が離脱す るときの $\theta$ の值 $\theta_{B}$ (図 13( i ) )は印加電圧の上昇とと もに大きくなる。これは, 気泡をトラップさせる電気 力が浮力より十分大きいためである。

I-CC 電極系ての $\theta_{B}$ を, 図 14 の実験系を使って 測定した。その結果が図 15 のプロットである。本研 究の電極サイズの場合, 電気破壊前の $\theta_{B}$ の最大值は $45^{\circ}$ 以上になっている。

ここで, $\mathrm{CC}$ 電極による観測で特に強調しておきた いのは, CS 電極の場合と違って, 高電圧条件下では $\theta=0$ 付近の気泡は溝内に完全にトラップされて, 決 してギャップ中に孤立気泡として出現しないことで

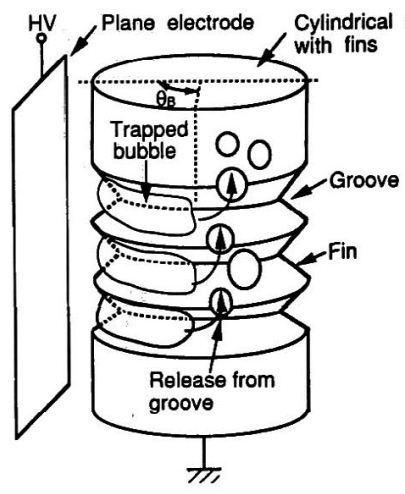

(i) Bubble behavior with CC-to plane electrode system

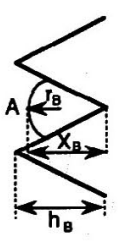

(ii) Bubble trapped in groove
図 $13 \mathrm{CC}$ 電極系の場合の気泡の基本挙動 とフィン間にトラップされた気泡

Fig. 13. Basic behavior of bubbles with CC-to-plane electrode system and bubble trapped in the groove.

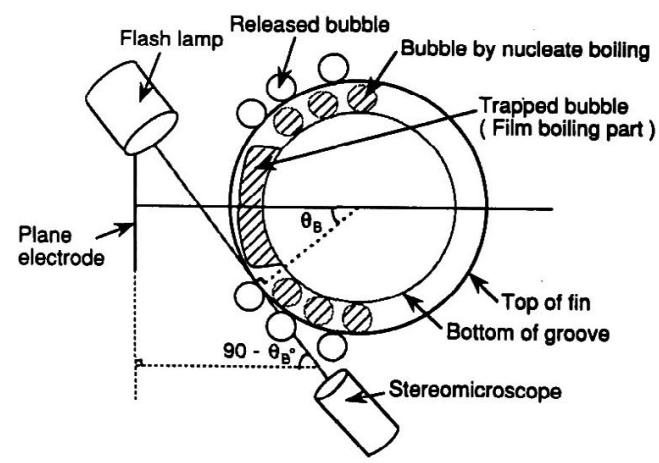

図 14 I-CC 電極系で気泡がフィン間から 離脱する位置 $\theta_{B}$ の測定法

Fig. 14. Measurement method of $\theta_{B}$ with I -CC electrode system. 


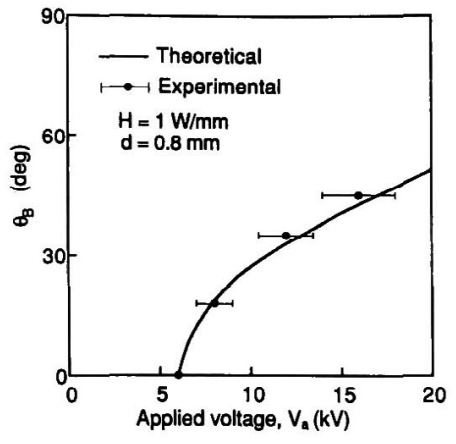

図 $15 \mathrm{I}-\mathrm{CC}$ 電極系における $\theta_{B}$ の計算值 と実験值の比較

Fig. 15. Comparison of experimental and theoretical values of $\theta_{B}$ with the I-CC electrode system.

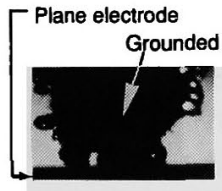

(i) $0 \mathrm{kV}$

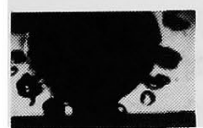

(iv) $9 \mathrm{kV}$

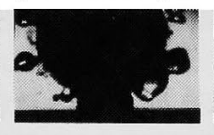

(ii) $3 \mathrm{kV}$

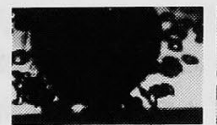

(v) $11 \mathrm{kV}$
$H=1 \mathrm{~W} / \mathrm{mm}, \mathrm{d}=0.8 \mathrm{~mm}$

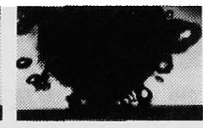

(iii) $6 \mathrm{kV}$

図 16 III-CL 電極系における高電界下の 気泡挙動

Fig. 16. Bubble behavior in the III - CL electrode system with DC high voltage.

ある。

III-CL 電極系では, 溝にトラップされた気泡がマ クロ不平等電界による電気力と浮力によって $\theta$ 方向 に移動するときフィン山を乗り越える必要がある。図 16 は, この電極系による気泡挙動の観測結果で, 電 気力と浮力によって溝にトラップされた気泡は, フィ ンによって電極系から放出することを遮られること と, 後続の気泡への熱侵入のために大きく成長して, フィン山を乗り越えてギャップ空間に放出され, マク ロ不平等電界の作るグレディエントカによって電極系 外に放出される。このフィンを乗り越えるとき, ギャ ップ間には, ガスに満たされたフィン先端対平板電極 系が構成され，電気絶緑上極めて厳しい条件になる。

（2）考察 フィン付き電極の場合も, マクロ
不平等電界成分は存在する。この成分の気泡挙動への 影響は〈3・1〉節で述べたのと同じであるので，ここで はミクロ不平等電界成分が引き起こすフィン近傍の現 象を中心に述べる。

（i）冷却促進と破塤電圧低下の防御可能なフィン 形状冷却促進のためには, 気泡を電極から容易に 離脱させることが大切であり，また，破壊電圧低下の 防御にはギャップの長さが最短になる領域で気泡によ るギャップのロックはもちろん，ギャップ中への気泡 の放出や成長を防ぐことが大切である。

まず，フィンを付けたとき, フィン先端の冷却効果 が大きいために，気泡は必ず谷から成長する。更に， 電圧を印加すると, フィン先端におけるグレディエン ト力は気泡をフィンから遠ざけるように作用し，その 大きさは破壊前に浮力の数十倍以上に達する(3)。従っ て, 溝内の気泡の逃げ道を作っておけば, 高電界下て フィン先端に気泡が安定に滞留することはない。

超電導体の長手方向にのみ溝をもつフィンを作るこ とは, フィンがマクロ不平等電界のグレディエントカ による気泡の移動を妨げ，ガス空間で満たされたギャ ップを形成する可能性が極めて高くなるので，避けな ければならない。

一方, 溝がマクロ不平等電界のグレディエント方向 に沿って作られていれば, 後で述べる機構によって, 溝にトラップされた気泡は溝に沿ってマクロ不平等電 界の低電界領域まで移動し，そこから液体中に放出さ れる。気泡内のガスがこのような溝に沿って流動する 場合は, 気泡がマクロ不平等電界の高電界領域でギャ ップ内に向かって成長することがないので, 耐電圧特 性の点からも好ましい。すなわち, 超電導線にフィン を付けてクエンチ時の冷却促進を期待し気泡による耐 電圧特性の著しい低下を防ぐためには, 超電導線の長 手方向と直角に溝をもつようにすることが大切と考元 られる。もちろん, 長手方向に沿った溝が付加されて も差し支えない。

実用の超電導成形より線では, 線の周りに緩やかな ピッチをもつ長手方向の溝をもっているが, これはク エンチ時の熱気泡破壊の観点からは極めて危険なフィ ン構造であり, 長手方向と直角な方向の溝の付加が望 まれる。

著者らの破壊特性に関する予備実験( ${ }^{(8)}$ によって, 長手方向にのみ溝をもつ場合には耐電圧がガス中の針 対平板に対する值近くまで容易に低下するが， $\theta$ 方向 に溝を設けると耐電圧が気泡の影響をほとんど受けな くなることを確認している。それらの詳細については 稿を改めて発表する予定である。 
（ii）フィン間にトラップされた気泡内ガス フィン間にトラップされた気泡に作用する圧力は, 静水压 $p_{a}$, 気泡内ガス圧 $p_{v}$, 表面張力による圧力

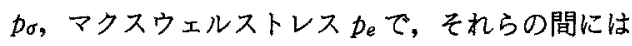

$$
p_{e}+p_{\sigma}=p_{v}-p_{a}
$$

の関係が成立する。なお，液体表面に作用する電気力 を，体積力を出発点として求めると，マクスウェルス トレス $p_{e m}$ とヘルムホルツストレス $p_{e n}$ のつの成分 が出てくる。しかし, 液体表面の平衡状態を考无る場 合には， $p_{e h}$ は電気ひずみ力による液体内の電気的圧 力と平衡するので，外的に観測される実効圧力は $p_{e m}$ のみとなり(9),ここではこれを $p_{e}$ とている。

上式で気泡表面の位置が決まれば $p_{e}$ は電界計算か ら求めることができ，また気泡のある位置の液面から の距離加的当求まるので, 気泡表面の曲率半径 $r_{B}$ を測定すれば $p_{v}$ を決定できる。ところが, 図 11 から わかるように $r_{B}$ を精度良く測定することは本実験系 では極めて困難である。粗い測定ではあるが，これを 行って $\left(p_{v}-p_{a}\right)$ を求めると約 $50 \mathrm{~N} / \mathrm{m}^{2}$ であった ${ }^{(8)}$ 。

ところで，図 14 の測定系で $\theta_{B}$ 近傍の気泡を入念に 調べると, 図 13(ii)に示す気泡表面の $A$ 点の谷から の距離 $x_{B}$ がフィン高さ $h_{B}$ 程度になると, 気泡が成 長して溝加ら放出されている。いま, 印加電圧 $V_{a}$ を 変えたときの各 $\theta_{B}$ に扔ける $r_{B}$ が等しいと仮定する と, 次の関係が成立する。

$$
\begin{array}{r}
p_{v}\left(V_{a 1}\right)=p_{a}+p_{e}\left(V_{a 1}, \theta_{B 1}, x_{B}=h_{B}\right)+p_{\sigma}\left(r_{B}\right) \\
\ldots \ldots \ldots \ldots \ldots \ldots \ldots \cdots \cdots \cdots \cdots(3) \\
p_{v}\left(V_{a 2}\right)=p_{a}+p_{e}\left(V_{a 2,}, \theta_{B 2}, x_{B}=h_{B}\right)+p_{\sigma}\left(r_{B}\right)
\end{array}
$$

ただし, 添字 1,2 は印加電圧 $V_{a 1}, V_{a 2}$ に対応する 值であることを示す。CC電極で $H=$ 一定のもとで は, 满内のガス圧は印加電圧には無関係と考元られる ので, $(3)=(4)$ となり, 次式が求まる。

$$
p_{e}\left(V_{a 1}, \theta_{B 1}, x_{B}=h_{B}\right)=p_{e}\left(V_{a 2}, \theta_{B 2}, x_{B}=h_{B}\right)
$$

すなわち，Hを与えたときの $\theta_{B} に$ にける $A$ 点での マクスウェルストレスはほほ一定と考えられる。

(5)式は $\theta_{B}-V_{a}$ 特性を与える理論式にもなってい る。 $p_{e}=100 \mathrm{~N} / \mathrm{m}^{2}$ と仮定して前報の理論( ${ }^{(3)}$ に基づい て $\theta_{B}-V_{a}$ 特性を求めると図 15 の実線のようになり, 測定值とよく一致する。この $p_{e}$ の值は, 先の $r_{B}$ の粗 い測定值から推定される值より高いが, オーダとして は同じである。すなわち，フィンにトラッブされた気 泡に作用するマクスウェルストレスが $100 \mathrm{~N} / \mathrm{m}^{2}$ オー ダ以下になると気泡が溝から放出される。このときの
気泡内ガス圧は, 静水圧より $130 \mathrm{~N} / \mathrm{m}^{2}$ 程度高く,こ の值は大気圧のわずか $0.13 \%$ ある。

\section{4. むすび}

円筒対平板電極系を液体窒素中に浸して熱気泡の挙 動を調べるとともに，気泡挙動に対するフィン形状の 効果を検討し, 次の結果を得た。

（1）液体窒素中でマク口不平等電界によるグレデ イエント力は浮力より十分に大きくなり得て, 孤立気 泡の運動を支配する。特に, 浮力とグレディエントカ が平衡する位置では, 気泡が滞留・合体してギャップ を橋絡することがある。しかし，電界分布をうまく選 定すれば，橋絡領域を液体の破壊以前に低電界領域に 押しやることができる。

（2）フィンによるミクロ不平等電界は，気泡をフ イン間の溝にトラップするように作用する。フィンに トラップされた気泡を高電界にさらすことなくマクロ 不平等電界の低電界領域に移動させるには, フィンの 作る溝をマクロ不平等電界のグレディエント方向に沿 つて作ればよい。

（3）平滑導体朽よびフィンによる溝方向がマクロ 不平等電界のグレディエント方向と直角になる場合に は, 高電界領域に気泡がさらされ，破壊電圧が気泡の 影響を受けるようになる。これに対し, 满をマクロ不 平等電界のグレディエント方向に沿って作ると, 上記 （2）によって破壊電圧が気泡の影響を受けないように なる。

（4）液体㗌素中でフィン間の溝にトラップされた 熱気泡内のガスは, 大気圧より $0.1 \%$ 程度高い状態に ある。

（5）電界によって気泡が発生する場合は, 気泡は 高電界形成点に最初に出現し, 破壊特性に決定的影響 を与えるが，本研究におけるように熱的に気泡が誘起 される場合は, 破壊電圧特性に対する気泡の影響を電 界制御によって著しく低減できる。

なお, 本研究によって推定された気泡挙動の破壊電 圧に対する影響の仕方は, 実験によって大部分確かめ られているが，それらの詳細は稿を改めて報告する。

最後に, 円筒電極に埋め込んだヒー夕用抵抗線 $(0.08 \mathrm{~mm} \phi)$ 表面の絶縁被覆に協力された(株)フジク ラの関係各位ならびに研究の初期の段階で実験に協力 された才田健二君に感謝する。本研究の一部は, 文部 省科学研究費, 抢よび九州大学一九州電力 (株) 総合技 術研究所間の共同研究によった。

(平成 5 年 6 月 17 日受付) 


\section{文献}

(1) M. Hara, T. Kaneko \& K. Honda: Cryogenics, 27, 93 (1987)

(2) M. Hara, K. Honda \& T. Kaneko: ibid, 27, 567 (1987)

（3）原・才田・斎藤：電学論 A, 113，337 (平 5-4)

(4) S. Shimamoto, T. Ando, T. Hiyama, H. Tuji, K. Yoshida, E. Tada, M. Nishi, K. Okuno, K. Koizumi \& K. Oda : Proc. of Symposium on Engineering Problems of Fusion Research, San Francisco Vol. 3, 1174 (1978)

(5) Hitachi Cable Ltd: Superconductor(Catalog), p. 19 (1989) Hitachi Cable Ltd.

（6）西川・藤田：伝熱学, p. 228（昭 60）理工学社

(7) C. G. Garton \& Z. Krasucki : Proc. Roy, Soc., A280, 211 (1966)

（8）原・才田・斎藤・王：電気学会放電研资，No. ED-93-5（平 5)

(9) J. A. Stratton: Electromagnetic Theory, First Edition, Chapter II (1941) Tenth Impression

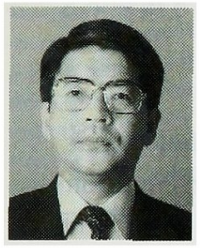

原雅 則（正員）

昭和 17 年 4 月 13 日生。 47 年 3 月九 州大学大学院工学研究科博士課程修了。 九州工業大学講師, 助教授, 九州大学助 教授を経て, 61 年同大学教授。電力工 学, 超電導工学, 静電バイオ工学に関する研究に従事。工 学博士。IEEE Senior, 低温・超伝導学会, 静電気学会, 放電研究グループ会員。

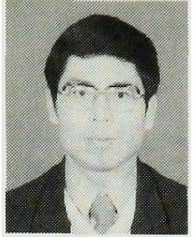

\section{王 振 朝 (准員)}

1958 年 4 月 15 日生。1987 年 1 月中国 華北電力学院修士課程修了後, 同学院講 師。平成 5 年 4 月九州大学大学院工学研 究科博士課程入学。現在, 超電導機器の 電気絶縁に関する研究に従事。

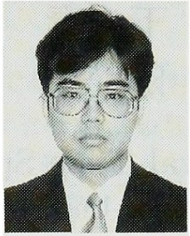

齋 藤 弘 勝（准員）

昭和 43 年 3 月 12 日生。平成 4 年 4 月 九州大学大学院工学研究科修士課程入 学。超電導機器の電気絶縁に関する研究 に従事。

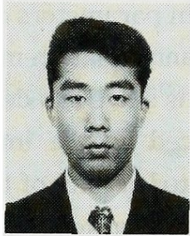

村 松悟 (准員)

昭和 45 年 12 月 14 日生。平成 5 年 4 月九州大学大学院工学研究科修士課程入 学。超電導機器の電気絶縁に関する研究 に従事。 